Volume 2, Number 1, 2016

\title{
Algorithmic Method for Precision Enhancement of Paper Pulp Blade Consistometer
}

\author{
Oleksandr Romaniuk ${ }^{*}$, Bohdan Kril, Oleksandr Kril \\ Lviv Polytechnic National University, 12, S. Bandery St., Lviv, 79013, Ukraine
}

Received: November 07, 2016. Revised: December 12, 2016. Accepted: December 23, 2016

(c) 2016 The Authors. Published by Lviv Polytechnic National University.

\begin{abstract}
The article deals with the algorithmic method for precision enhancement of paper pulp blade consistometers . In the said method, the current strength in the winding of a moving coil of a magnetoelectric transducer in the steady regime of sensor's blade motion condition is measured during its movement in downstream and upstream directions. Thus, we can minimize the error resulting from the impact of changes in flow velocity relative to paper pulp measuring blade of the consistometer. Schematic diagram of a paper pulp consistometer with paper pulp flow velocity compensation is presented. Dependence of voltage and current versus time on the outputs of the main blocks of presented paper pulp consistometer with compensation of paper pulp flow velocity influence is considered. Influence of paper pulp flow velocity and consistency on the dependencies of current versus time for the coil of a magnetoelectric transducer of a paper pulp consistometer is described.
\end{abstract}

Keywords: blade consistometer; blade consistency meter; paper pulp; consistency; non-Newtonian fluid.

\section{Definition of the problem to be solved}

Paper making industry is very important in modern industrial countries. First of all, it produces various package materials, which can be easily utilized by repeated recycling, giving as value production as from initial (starting) raw materials [1]. The processes of paper pulp recycling can be realized on large high capacity technological lines, as well as on relatively small ones. Moreover, this small production line shall be economically effective due to reduction of expenses for transportation of raw materials and ready-made products, and decrease of technological loading on environment. An important technological parameter in paper making industry is consistency (concentration) of paper pulp [2]. It is measured indirectly by measuring paper pulp viscosity, and is one of the few examples of medium concentration determination by measuring its viscosity $[3,4]$. The metrological and operational parameters of instruments developed for measuring paper pulp consistency can be improved by modification of measuring process with further algorithmic processing of the directly measured values. Below, the improved version of a blade consistency meter for paper pulp is presented in which the influence of paper pulp flow rate on the value of measured pulp consistency is considerably reduced.

\section{Analysis of the recent designs of the blade consistency meter devices}

There are several technical arrangements of blade consistency meter devices for paper pulp appropriate for industrial application. The most famous of them are as follows.

Blade consistency meter design without activator (activating agent) [5, 6, 7].

In this consistometer design, the blade is placed along the paper pulp flow. Paper pulp consistency is determined by the viscous friction force acting on the blade by the pulp flow. The value of the force acting on the blade varies approximately within the limits of 0 to $30 \mathrm{~N}$ when the paper pulp consistency varies 0 to $16 \%$ Cs. For different ranges of measurements and various paper or cellulose, fibers structures blades of different design are used. Calib-

*Corresponding author. Email address: o.m.romaniuk@gmail.com 
ration of devices is carried out individually by means of the results of laboratory tests for each specific application. For consistometers, the parameters of the force acting on the measuring blade are normed in the way that the sum of all components of error in measuring force (non-linearity, hysteresis, influence of the static media pressure) does not to exceed $1 \%$. Conditions of consistometer installation are determinative. To access the maximum accuracy, we have to eliminate stream turbulence, eliminate the possibility of dead-air space (air bubbles) formation and pulp separation in the vicinity of the consistometer blade. Taking into account the abovementioned factors and the calibration procedure the resulting relative error referred to, full-scale value of $5 \%$ is considered acceptable. The blade consistometers of this design have limitations on the value of the tolerance for paper pulp flow velocity variation. In [5], the diagrams for different blade designs with tolerance range for paper pulp flow velocity and the range of paper pulp consistency measurement are presented. If the paper pulp flow velocity drops out of the recommended range, the correction must be applied in the measured consistency value.

Blade consistency meter design with an activator $[8,9]$.

In this consistometer, the blade is set into periodical motion by a magnetoelectric transducer (activator). Microprocessor unit measures the time it takes for the blade to pass the distance from the limiter to the optical location sensor. Using the measured time, the microprocessor unit computes the paper pulp consistency. In this design of a blade consistometer, the shear rate of the paper pulp in the vicinity of a sensitive blade in the process of viscosity and consistency measurement is artificially increased. It is obvious, that the influence of paper pulp flow velocity on the result of consistency measurement by the described here blade consistometer design with periodically mowing blade will be less, than in described above with stable blade. The main sources of errors are the same as in the previous blade consistency meter design. The place of consistometer installation is important. The dead-air space (air bubbles) formation, pulp separation, and precipitation have not appeared in the vicinity of the consistometer blade. The pulp pressure pulsation caused by pulp pump operation must be minimized. The calibration procedure of devices is carried out for different types of paper pulp similar to procedure for blade consistency meter design without activator.

Summing up the abovementioned, both blade consistency meters allow paper pulp viscosity measurements with the satisfactory high accuracy in ideal conditions. To determine the paper pulp consistency by the value of viscosity, it is necessary to meet a number of conditions: decrease the influence of the non-informative parameters on the measuring process, and to provide the correct calibration of devices with non-linear static characteristics.

Minimal dead-air space (air bubbles) formation, pulp separation, and maximal sample representability will be present in the centre of the paper pulp pipe. However, the maximal flow velocity will be present in the same place. Therefore, study of decrease of paper pulp flow velocity influence on the process of consistency measurement by blade consistency meters is the subject of an advanced research.

\section{Formulation of the goal of the paper.}

Further investigations are aimed at the improvement and development of a paper pulp blade consistometer in which the influence of the paper pulp flow velocity in the pipe on the result of consistency measurement is significantly reduced by means of measurement process improvement and algorithmic processing of the measuring results.

\section{Presentation and discussion of the research results.}

In the modified design of a paper pulp blade consistometer, the movable blade accomplishes oscillations with constant velocity of movement in both directions from the average position. At the same time, the current strength in winding of the moving coil of a magnetoelectric activator (transducer) is measured. Its values in the steady blade motion regimes should be different depending on the direction of blade motion with respect to paper pulp flow direction, and depending on paper pulp consistency.

The principle of operation of the described consistometer is illustrated in schematic diagram in Fig. 1.

In the proposed consistometer design, the blade 2 performs oscillations relatively to its average position, which is shifted by determined angle relatively the axis of the pulp pipe 1 with the constant on absolute value but signchanging velocity. The velocity and amplitude of blade oscillations are measured by the receiving transducer of bar displacement 6 , and are set by triangular pulse generator 7 . The following proportional control system consists of the differential amplifier 8 and the power amplifier 9, and ensures maximal proximity of the amplitude and velocity of the moving blade 2 to the form of pulses on the exit of triangular pulse generator 7 . The motion of the blade is 
ensured by the magnetoelectric transducer, which consists of a coil and a permanent magnet system 5 . The current force in the coil of the transducer is measured by a voltage drop across a resistor 10. This current force will be proportional to the force value needed for the blade displacement in moving paper pulp medium with definite pulp consistency. After the direction of the blade motion changes to the opposite one, the current force through the coil of magnetoelectric transducer increases dramatically, and in some time decreases to a new stable value as the blade velocity approaches to the stable preset value. Measured in these moments, the current force provides information on consistency and flow velocity of the paper pulp. When the blade moves down the pulp flow, the current force will be smaller, meanwhile if it moves against the pulp flow, the current force will be greater. By means of further algorithmic processing the useful output information, in which the influence of paper pulp flow velocity will be eliminated, will be obtained. We shall note that the issue of temperature compensation of paper pulp consistency readings will not be considered in the present article, therefore the channel for paper pulp temperature control is not shown in Fig. 1.

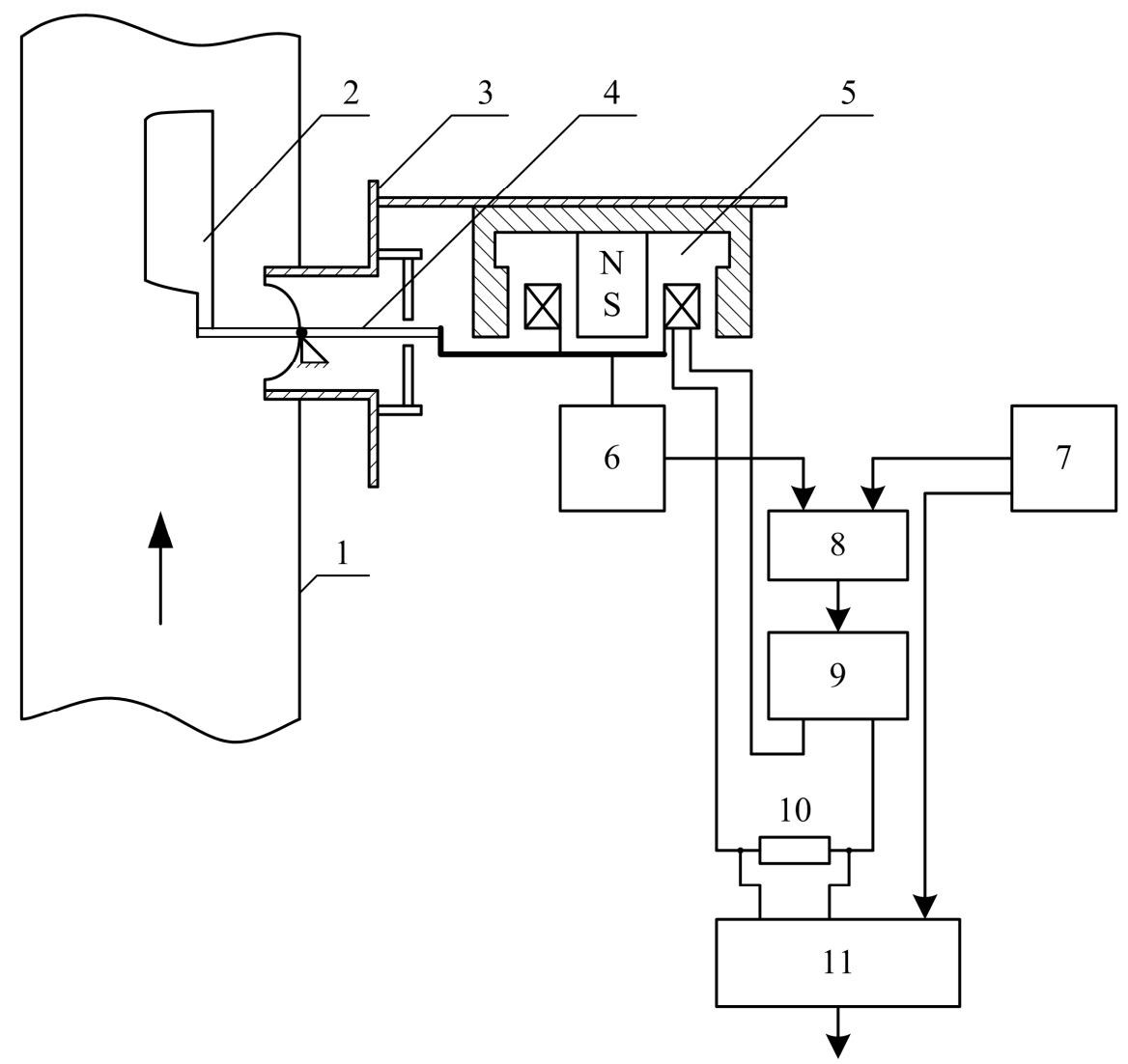

Fig. 1. Schematic diagram of a paper pulp consistometer with paper pulp flow velocity compensation:

1 - pulp carrying pipeline; 2 - movable blade of a consistometer; 3 - consistometer housing; 4 - a bar (arm), on one side of which a sensitive blade is fixed, on the other one a the coil of magnetoelectric activator. In the middle of the bar the space is sealed by elastic diaphragm. 5 - magnetic system of the magnetoelectric activator (transducer);

6 - receiving transducer of bar displacement; 7 - triangular pulse generator; 8 - differential amplifier;

9 - power amplifier; 10 - resistor for measurement of current force in the coil of magnetoelectric transducer; 11 - microcontroller system for information processing and connection with display system and technological process control system

In more detail, the operation of the considered design of a paper pulp consistometer is explained by graphs of voltage and current on time on the output of the main blocks of consistometer presented in Fig. 2.

In Fig. 2 the plot 1 - presents the pulses of correct triangular pulse generator 7 . The following system drives the movable consistometer blade by means of a magnetoelectric transducer. Plot 2 presents time to voltage dependence on the exit of sensor of blade displacement transducer. There are some distorted triangular pulses, so the following system does not provide the motion of the moving blade in accordance with ideal triangle dependence on time in the first moments after reversing direction of blade motion. Plot 3 presents the difference of the two former plots, it is 
produced by the differential amplifier. The greatest disagreement is observed right after the moments when the direction of the blade motion changes on opposite one. Plot 4 presents the current dependence in the coil of a magnetoelectric transducer that sets into motion sensitive blade of transducer. Just the magnitude of this current gives the useful information on the paper pulp consistency. It is obvious that we must measure the current strength in some short time delay after the moment when the blade motion direction is reversed into the opposite one, when the servosystem will already provide the constant velocity of blade motion in the paper pulp. For simplicity, all graphs considered in Fig. 2 are presented with the absent paper flow.

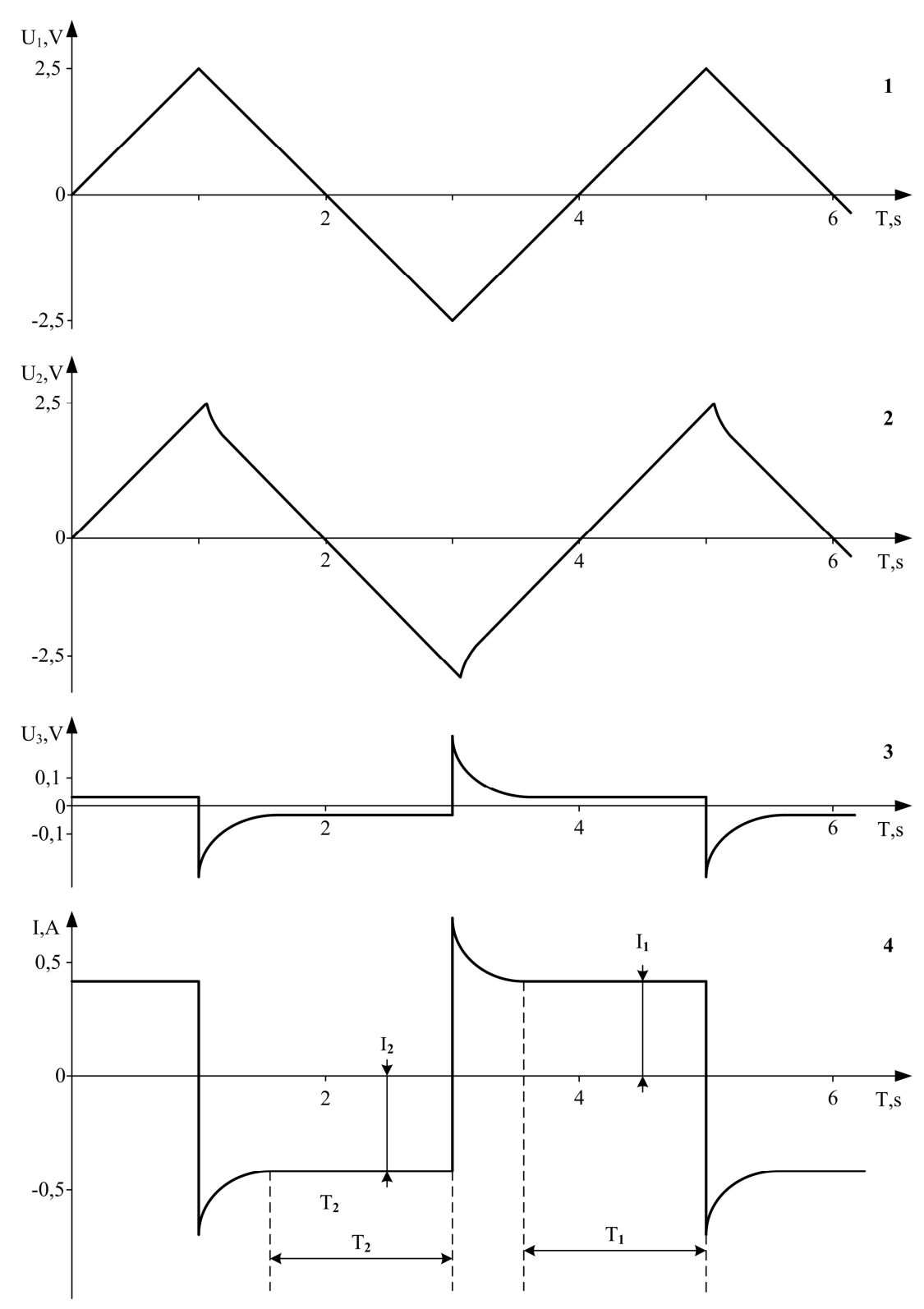

Fig. 2. Plots of voltage and current versus time on the output of the main blocks of presented paper pulp consistometer with compensation of the paper pulp flow velocity influence.

For simplification, the plots are presented for condition, when paper pulp flow velocity equals to zero (paper pulp does not flow), and paper pulp consistency is constant: 1 - plot of voltage versus time on the exit of the triangular pulse generator;

2 - plot of voltage versus time on the exit of the blade displacement transducer; 3 - plot of voltage versus time on the exit of a differential amplifier; 4 - plot of current versus time on the exit of coil of magnetoelectric transducer

The view of the graphs, except the first one, will change if the paper pulp begins to flow because in this case the relative pulp-to blade velocity will be different for the downstream and upstream blade motion. If the blade moves downstream, the relative pulp - to blade velocity will be equal to difference of pulp flow velocity and blade velocity, 
measured against the tube. If the blade moves upstream, the relative pulp - to blade velocity will be equal to the sum of pulp flow velocity and blade velocity. Therefore, when the blade moves downstream, it experiences less viscous force than in a streamless paper pulp, and will experience a greater viscous force, moving upstream. These processes are illustrated by graphs in Fig. 3.

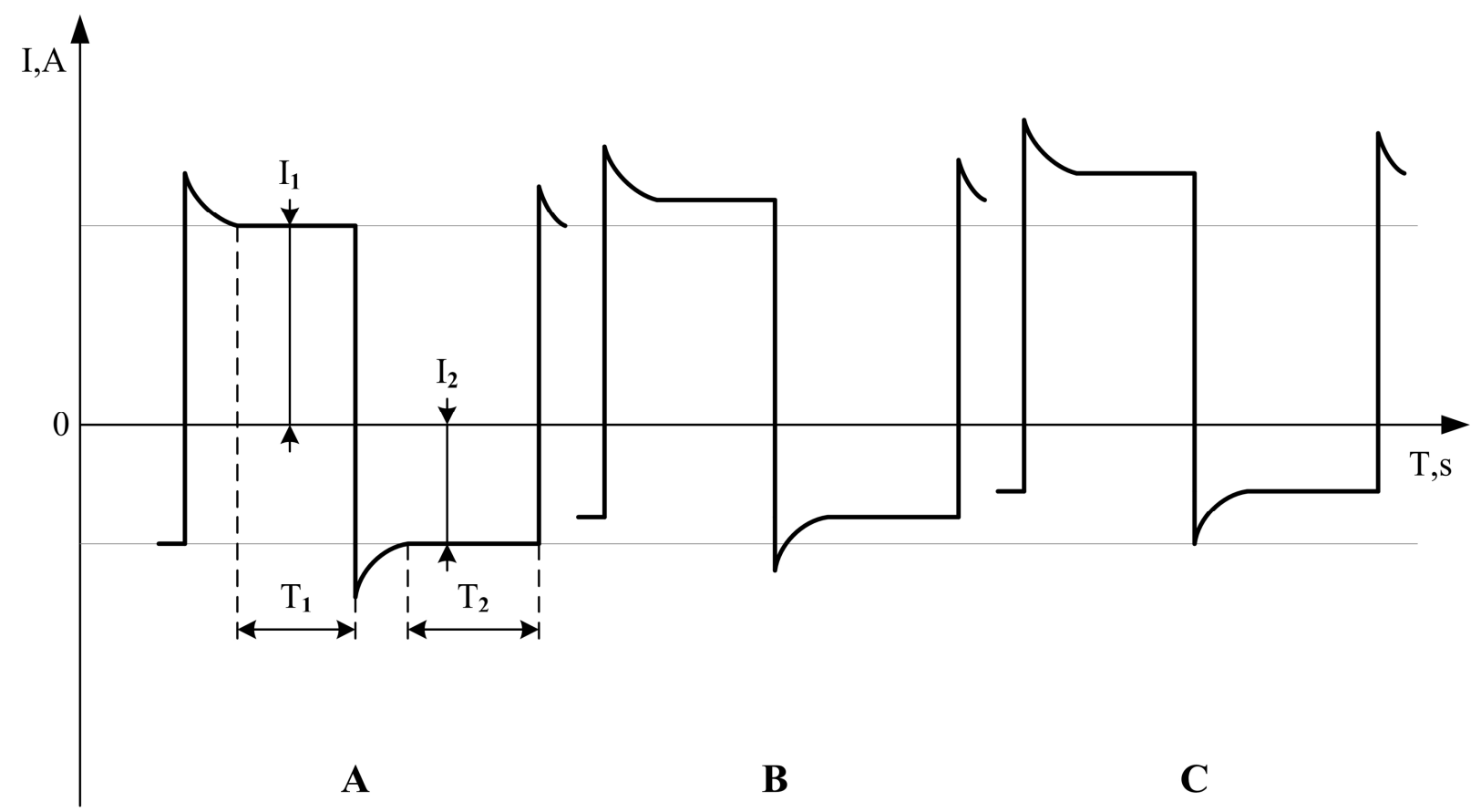

Fig. 3. Plots of current versus time for the coil of a magnetoelectric transducer of a paper pulp consistometer at three different values of the paper pulp flow velocities $\left(\mathrm{V}_{\mathrm{A}}<\mathrm{V}_{\mathrm{B}}<\mathrm{V}_{\mathrm{C}}\right)$ and a constant value of paper pulp consistency

In Fig. 3 plots of current versus time for the coil of a magnetoelectric transducer of paper pulp consistometer at a constant value of paper pulp concentration and for three different values of the paper pulp flow velocities in increasing order of magnitude are presented.

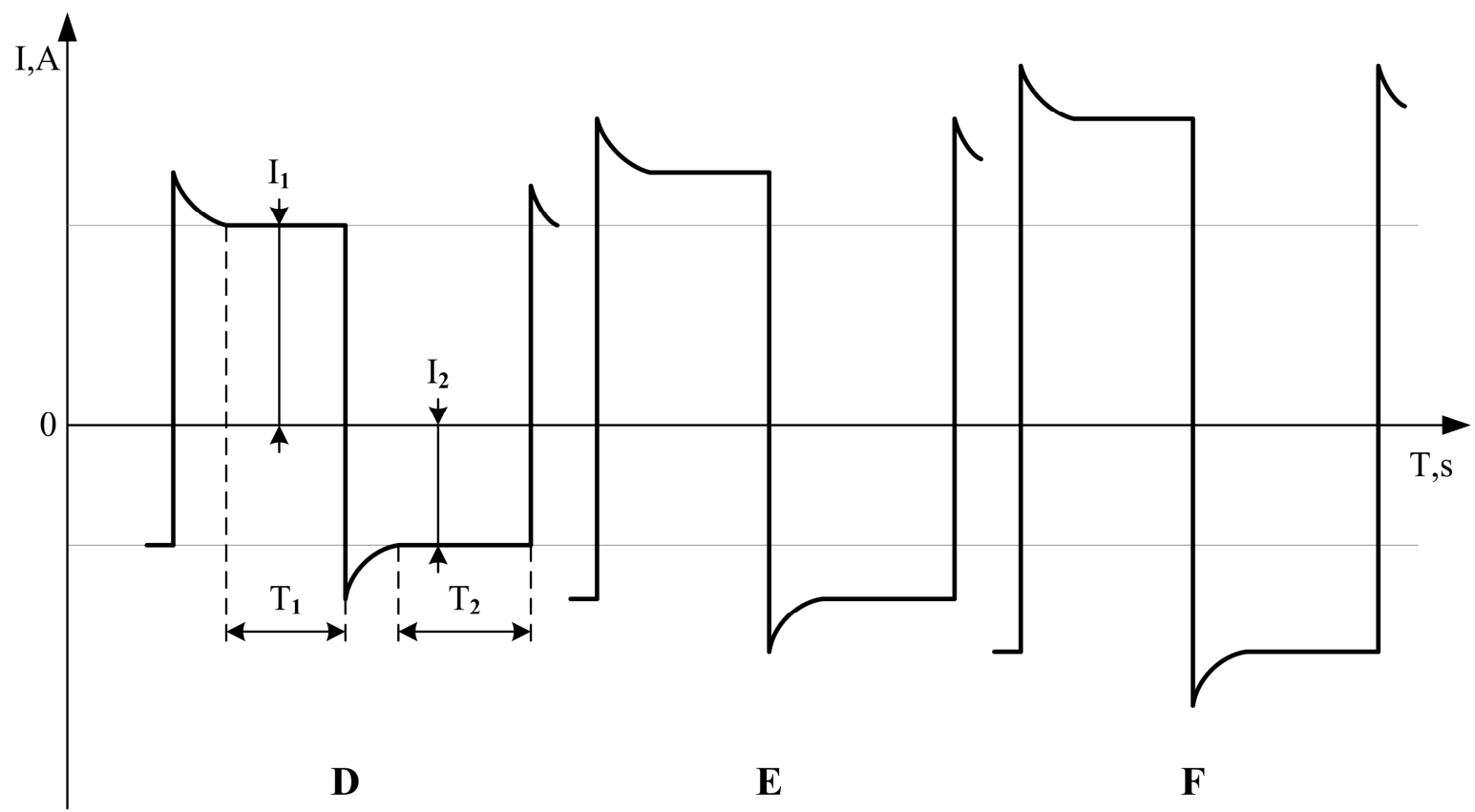

Fig. 4. Plots of current versus time for the coil of magnetoelectric transducer of paper pulp consistometer at three different values of pape pulp consistency $\left(\mathrm{C}_{\mathrm{D}}<\mathrm{C}_{\mathrm{E}}<\mathrm{C}_{\mathrm{F}}\right)$ and constant value of the paper pulp flow velocity 
It is shown in Fig. 3 that in the steady-state blade motion regime the current amplitude in the case of a downstream blade motion and upstream blade motion differ from each other, and this difference grows when the paper pulp flow velocity is increasing. However, the sum of current amplitudes remains constant and independent of the moving velocity of the paper pulp flow. If an algorithm of valid signal processing using this graph property is designed in the paper pulp consistometer we will manage to compensate the influence of the paper pulp flow velocity on the measured pulp consistency data.

The current versus time plot of the coil of a magnetoelectric consistency transducer of paper pulp consistometer for three different values of paper pulp consistency and constant value of the paper pulp flow velocity are presented in Fig. 4.

These three plots of current versus time for the coil of magnetoelectric transducer for three different values of paper pulp consistency in increasing order of magnitude differ from each other by the current amplitude in the steadystate blade motion regime for downstream and upstream directions of blade motion. It is obvious, that there will be the multiplicative type of influence of the paper pulp consistency on the positive and negative current amplitudes, which can be taken into account algorithmically.

In the process of paper pulp consistency measurements in a real technological process the plots of current versus time for the coil of the magnetoelectric transducer will be affected by the simultaneous change of the value of the paper pulp flow velocity, as well as paper pulp consistency, as it is described in the comments to Fig.3 and Fig. 4.

Let us explain in complete detail the realization of a paper pulp consistometer in accordance with proposed scheme.

The design the of the primary consistency transducer with the movable blade has no particular differences from the known analog [8], except that the blade can move with an equal deflection in both directions with respect to the average position, which is shifted by determined angle relatively the axis of the pulp pipe. Another difference is the smaller blade dimensions without sacrificing the measuring precision. To realize the proposed algorithm of pulp consistency measurements, the primary transducer is supplied with a location transducer of a lever arm with sensitive blade. Location transducer can be realized using one of the three following principles for producing sensors of displacement measurements: magnetoresistive effect, Hall effect, or electromagnetic induction effect.

Magnetoresistive transducers have been used in early position sensing systems. Their main weak point, same as of the systems based on Hall effect, is the thermal dependence of the transfer functions of the positioning system. It is possible to go without special temperature compensation of the transfer functions of the positioning system and consider it only on the stage of taking into account correction of a resulting systematic error of the entire consistometer, but in further research we plan to employ a modification of the induction sensor - differentialtransformer that operates at high frequency. Despite the fact it is technologically unfeasible, this transducer has significantly less temperature dependence of the transfer function. At last, for the mechanical system of the modified blade consistometer the static balancing of the movable mechanical part in the work position is important. This demand was not critical for previous transmitter designs, but in this design balancing of the movable system can help avoid the procedure of taking into account of mass distribution in movable part of sensor during algorithmic data processing.

The sheet-oriented realization of the electronic assembly units of the measuring circuit has no special features. Triangular pulse generator can generate one constant frequency or, for broadening of the functionality two or three preset frequencies that can be switched by a microcontroller. Two preset frequencies are used to extend the measuring range and the last, much higher value - is used for service operation - periodical blade shake-up to clean the blade from possibly adhering long fibered materials.

It is reasonable to perform this algorithmic processing by means of a serial low powered microcontroller. Authors have a number of realized technological measuring devices with application of low-powered freely programmable microcontrollers of S7-200 and S7-1200 series produced by the Siemens AG engineering company [10]. Their programmable and networking capabilities significantly reduce the time and costs for development and technical realization of small volume manufacturing or development and production of single technological measuring instruments and systems. 


\title{
5. Conclusions
}

By means of modification of the process of paper pulp consistency measurement by means of a blade consistometer and further algorithmic processing of the measured current force values in the coil of the magnetoelectric transducer, which sets the sensor blade into motion, it is possible to reduce the influence of variation of paper pulp flow velocity on the result of the paper pulp consistency measurement. The charts presented by the authors explain the principle of information processing and the principle of compensation of the paper pulp flow velocity variations on the measured pulp consistency for the developed design of a paper pulp consistometer.

\section{References}

[1] Waller M. H. (1993) A tutorial on the measurement of paper stock consistency. ISA Transactions, 32, pp. $277-282$.

[2] Osipov P. S., (editor) (2002) Technology of pulp and paper production, vol. 1. Raw materials and production of semi-finished products, Politehnika Publ., Saint Petersburg, 425 p. (in Russian)

[3] Schramm G. A. (2000) Practical Approach to Rheology and Rheometry. $2^{\text {nd }}$ Edition, Gebrueder HAAKE GmbH, Karlsruhe, Federal Republic of Germany. - 291 p.

[4] Steffe J. F. (1996) Rheological Methods in Food Process Engineering. $2^{\text {nd }}$ Ed. Freeman Press, East Lansing, MI, USA. - 418 p.

[5] Valmet Blade Consistency Transmitter - Valmet SP Installation and User's Manual, Valmet Automation Inc., Kajaani, Finland. - 2015.

[6] Metso Blade Consistency Transmitter. Installation and User's Manual K11389 V1.1 EN Metso Automation Inc. Documentation: Metso Automation / Marjo Nygård Copyright C December 2012.

[7] Wall, H. A. (1968) Consistency measuring apparatus. US Patent No. US 3364730 A.

[8] “MBT-2500 User manual” (2007) BTG Pulp and Paper Technology AB, Säffle, Sweden.

[9] Skallen, B. (1989) Method and apparatus for measuring the viscosity of a medium. US Patent No US4875362.

[10] Romaniuk, O. M., Kril, B. A., (2015) Precision enhancement of rotational viscometers by algorithmic method. Materials of $2^{\text {nd }}$ International scientific and technical conference "Modern methods, informational, programmable, and technical support of the organizational, technical and technological complex control systems”. Kyiv, NUFT, pp. 71-72 (in Ukrainian).

\section{Алгоритмічний метод підвищення точності лопаткових концентратомірів паперової маси}

\author{
Олександр Романюк, Богдан Кріль, Олександр Кріль \\ Національний університет «Львівська політехніка», вул. С. Бандери, 12, Львів, 79013, Україна
}

\section{Анотація}

Розглянуто алгоритмічний метод підвищення точності лопаткових концентратомірів, у разі реалізації якого вимірюється сила струму через навитку магнітоелектричного перетворювача в усталеному режимі під час руху вимірювальної лопатки в обидва боки. У такий спосіб можна мінімізувати похибку, яка виникає внаслідок впливу зміни швидкості течії паперової пульпи відносно вимірювальної лопатки концентратоміра. Наведено блок - схему концентратоміра паперової пульпи 3 компенсацією впливу швидкості потоку паперової пульпи. Розглянуто залежності від часу струму та напруги на виходах головних блоків запропонованого концентратоміра паперової пульпи. Описано вплив швидкості течії та концентрації паперової пульпи на залежності струму через навитку магнітоелектричного перетворювача від часу.

Ключові слова: лопатковий концентратомір; паперова маса; концентрація; неньютонівська рідина. 